\title{
The Effect of Using Wattpad on Process-Genre Approach towards Writing Achievement in Tertiary Level
}

\author{
Rendhi Fatrisna Yuniar ${ }^{1}$, Utami Widiati ${ }^{1}$, Utari Praba Astuti ${ }^{1}$ \\ ${ }^{1}$ Pendidikan Bahasa Inggris-Universitas Negeri Malang
}

\section{INFO ARTIKEL}

\section{Riwayat Artikel:}

Diterima: 11-02-2019

Disetujui: 22-07-2019

\section{Kata kunci:}

wattpad;

process-genre approach;

writing ability;

ESP students

\author{
Alamat Korespondensi: \\ Rendhi Fatrisna Yuniar \\ Pendidikan Bahasa Inggris \\ Universitas Negeri Malang \\ Jalan Semarang 5 Malang \\ Email: rendhify@gmail.com
}

\section{ABSTRAK}

\begin{abstract}
This paper presents the integration between the use of technology and conventional learning and teaching process. Taking advantage of technology in classroom like the use of Wattpad by integrating with process-genre approach helps students to make the classroom activities become more efficient. This objective of this paper is to show the effect of using Wattpad in teaching and learning process by integrating with process genre approach towards students' writing achievement. The treatment starts from pretest, and end with post-test. The result in this study shows after the students teach by using Wattpad gain better writing achievement than before using it.
\end{abstract}

\begin{abstract}
Abstrak: Penelitian ini berisi tentang integrasi antara penggunaan teknologi dan pembelajaran konvensional pada proses pembelajaran. Mengambil kelebihan dari teknologi pada pembelajaran di kelas, seperti penggunaan Wattpad dengan mengintegrasikan pendekatan Process-genre, hal ini meningkatkan tingkat keefisiensian kegiatan pemblejaran di kelas. Penelitian ini bertujuan untuk melihat keefektifan penggunaan Wattpad yang diintegerasikan dengan pendekatan process-genre pada proses pembelajaran terhadap penacapaian menulis siswa. Penelitian yang dilakukan dimulai dari pretest dan diakhiri dengan posttest. Hasil dari penelitian ini menunjukkan siswa yang telah belajar menggunakan Wattpad memiliki pencapaian menulis yang lebih baik daripada sebelum menggunakannya.
\end{abstract}

EFL learners of English have difficulties on practicing and acquiring English. Some studies reveal that writing is the most complex and difficult skill to master since it involves high cognitive processes ((Hamman, 2005; Santangelo, Harris, \& Graham, 2008; Talebinezhad \& Negari, 2007; Villalon \& Calvo, 2011; Wahyuni, 2014). Writing does not develop communication skills only, but also a higher level of cognitive processes. More particularly, writing is one of the skills which is very crucial to be mastered. Writing is really important because it influences the way of thinking and also the personal development through clarifying and organizing our personal as we write. According to (Richards \& Renandya, 2002), Foreign language learners have difficulties in Writing caused by some aspects, namely generating idea, organizing the ideas and structures, and linguistic problems. (Santoro, Reid, Mayer, \& Singh, 2012) states that discovering, organizing, reshaping, and revising are the processes of writing. Composing a paragraph or a text by adding evidence and support sentences are related to writing in English language education. In addition, all the components of writing such as unity in the topic, smooth organization of ideas, the suitable diction use, grammatical correctness, and correct mechanics have to be met in good writing (Abdul, 2014). Due to the complexity of writing, college students cannot avoid having the difficulties of writing and barely to solve it. However, college students have the responsibility to solve the writing problems since they have obligated to produce writing products in the end of their programs.

Many EFL writing teachers state that they fail to solve the problems on writing, especially in a traditional class. A traditional class refers to class that uses conventional method and does not integrate technology in teaching and learning process. Since students has been familiarized by the use of technology, the teaching method that is applied in class should follow the times. One of the factors that plays a role on students' writing failure in a traditional class is caused by the neglection of communicative aspects. Traditional class tend to focuses on how to write good sentences rather than how to communicate the meaning. Hukom (2007) stated that teachers who use conventional methods tend to focus on student writing production rather than writing activity itself and it happens ceaselessly. However, writing process and how the idea is generated need to be emphasized rather than merely focussing on the result (Hyland, 2003). 
One of the effective approaches in writing is process approach. Process approach is an approach which focus on students writing process than merely focusses on students' writing product. Process oriented should be more focused in teaching writing for second language learner students. Pre-writing, drafting, revising, and editing are the steps which aid students in writing process. The process of writing is considered as a crucial component in writing (Gordani , 2012). The focus on writing is not only the final result, but also the process of writing activity itself. Unfortunately, process-based approach also has some drawbacks which one of those is the long training period required for both, the teacher and also the students. Another disadvantage of this approach is not clearly guidance on how do the writers construct different kinds of text.

To minimize process-based approach drawback, the researcher combines them into genre-based approach. The genres on genre-based approach are divided into narrative, recount, argumentative, exposition, procedure, report, and descriptive. Since genre-based approach classifies genres of text types into several classification, it helps teacher and students to comprehend the different features of target genres. Building knowledge of field, modelling of the text, join construction of the text, and independent construction of the text are the phases that help students on producing writing product. Moreover, genre is claimed by Ahn (2012) is a mean to teach English for Specific purposes on Writing. The accessibility and the participation involvement are the objective of this approach. By combining the advantages of process-based approach and genre-based approach, the students are expected to master on how to produce and link their ideas, make process of writing transparent, know how to express social purposes effectively, and make textual conventions transparent.

The drawbacks of process approach and genre approach are minimized by combining these approaches into one approach. This combination commonly called as process-genre approach. Focusing on students' writing practice rather than the result only is the advantage of this combination approach. The process-genre approach once be done by Badger and White (2000). Fruitful result is gained when it was implemented on teaching argumentative text for ESP students. The components contained in prosesgenre based approach are building knowledge, modelling, pre-writing, joining construction, drafting, constructing text individually, writing, revising, and editing. The components in process-based approach is encountered in joining construction and constructing individual text. A study conducted by Badger and White (2000) shows positive effects of using process-genre approach after removing joining construction and constructing text individually elements. Pre-writing in proses-genre approach are integrated with modelling element to see whether or not the text produced by the students achieve the same criteria or not. Previous studies conducted by Badger \& White (2000) and Yan (2005) show positive effect result after applying the processgenre approach with clear instruction and in recursive way of process. Significant results of process-genre approach implementation on students' argumentative text achievement was gained after the implementation of the aforementioned approach and Wattpad as the medium. However, a study conducted by Mingli (2012) shows the failure of using process-genre approach since the result showed that the combination of process and genre approach was not more effective compared to the traditional one.

Wattpad is one of media which permits the users to access, interact, give and receive feedbacks with other users. Wattpad is the world's largest social media in which people can write or share their stories or utter their opinions about something. Wattpad is a platform to share and aspire writers' idea and connect with other readers or writers (Ramdarshan Bold, 2018). Since the increase of social media users from years to years, the researcher thought that Wattpad can be an adequate medium to enhance students' writing ability. Creative process of writing is provided by Wattpad as platform for writing and reading (Jenkins, 2006; Rifkin, 2014). So, that can be said that Wattpad can trigger the students' creativity to write about their opinions. In addition, the students can be both editors or writers since Wattpad connects the writers from any countries. Direct comment, non-direct comment, and suggestion can be given by the readers to help the writer's writing development. Besides, Wattpad is an online platform which can be seen through web or application. Wattpad users only need to type and publish it instantly after the registration process. In addition, the users can sign in through their gadget anywhere and anytime without any obstruction. Wattpad is a medium which promises solutions to the time-limited issue. By using this medium, students and teacher can conduct discussion anytime and anywhere.

There is a study that shows the disadvantages of using Wattpad. The study conducted by (Aytan, 2017) shows that the Turkish teachers tend to think that Wattpad has drawbacks such as low concentration, distractibility, copyright and plagiarism concerns and many more compared with handwriting. Some people in Turkish who had electronic writing experience stated that low concentration on students writing process is one of the effects of the eye problems and suffer headaches which is caused of paying concentration on the screen for a long time. They think that health problems along it cannot be evaded during writing process. The decrease of students' writing quality is one of the effects on the low level of concentration during the writing process. Distraction is one of the other problems in electronic environment since a few websites can be used in the same time. Furthermore, when the students are distracted by other websites, it can decrease students' focus on doing their writing product. The other issue comes up from the higher number of copyright and plagiarism. Copyright and plagiarism issues should be considered since some quotes can be copied and shared easily without specifying the sources. Due to the involvement of originality as one of the aspects that should be contemplated in writing, the high level of plagiarism could reduce students' writing quality. However, the effect of using Wattpad cannot be judged from negative point only, but also from both the negative and the positive points. Some studies 
about Wattpad (Aytan, 2017; Contreras, Gonzaga, Trovela, \& Kagaoan, 2015; Ramdarshan Bold, 2018) show that students taught using Wattpad perform better achievement in writing than using face to face feedback. It proves that Wattpad can utilize the students with useful and meaningful learning in writing essay since they become more active and cooperative. Students have more bravery to express their opinions and ask questions. The level of students' hesitation in writing and giving comments also decrease since they have more time to study. Another study was conducted by (Ramdarshan Bold, 2018) which shows that Wattpad gives new way on readers and writers interaction. While a study conducted by (Contreras et al., 2015) shows that Wattpad has become part of the participant - readers' lives, it also becomes a big role not just as a medium for writing, but also as a medium that gratifies the participants' emotional and cognitive needs and wants.

According to the previous studies, none of these studies are conducted to examine the use of Wattpad in English teaching and learning context, especially in Indonesia. Moreover, the opportunity on applying a popular medium in class will aid the learners to use it since it is familiar with them. The high number of Wattpad usage in Indonesia can be beneficially applied in learning process. As most of previous studies focused on the features, there is a need to conduct further research in regard to writing aspects such as content, organization, grammatical, vocabulary, and mechanic. Several gaps concerning in previous studies are the basis to conduct this study. In this study, the researcher proposes a different focus of previous studies in the term of using Wattpad. The researcher proposes Wattpad as a medium to be examined whether or not it brings positive effects to students' writing achievement.

The present study is different from previous studies. Previous studies tend to be conducted experimental research This study investigates the effect of students' achievement in writing argumentative text by using Wattpad as the media on processgenre approach. Wattpad has not been analysed by other researchers in relation with argumentative. After all, the relation between technology integration in teaching writing has not been conducted yet. All the gaps are explained to affirm that the topic chosen is worthy to be conducted. Based on the background of the study presented formerly, the aim of this study is to investigate the effectiveness of using Wattpad on writing argumentative text. The research questions used are formulated as questions follow "Do the students taught by using "Wattpad" gain better achievement in writing than the students taught by using traditional method?"

The theoretical hypothesis addressed from the research questions above are: The belief, the so-called assumption, is that there is an effect of using "Wattpad" in teaching writing for college students. In order to have tentative answer towards the research problem, two hypotheca related to the problem is presented as follow "Students taught using "Wattpad" have better writing achievement than the students taught without using it".

Practical and theoretical contribution are expected to be found in English Learning and Teaching activity in general and writing technique in particular. Theoretically, the result of this study is expected to give significant contribution by providing important information related to integration of technology in learning and teaching. The information of better strategy in teaching writing is also expected to be gained. Practically, the result of this study is presented as significant background to those who are interested in teaching and learning, especially in writing context. This study also can be used as other researchers' reference in conducting further research.

\section{METHOD}

Generally, the objective of experimental research is to know the cause-effect relationship of variables. In addition to that, experimental research can be used to measure the effectiveness of particular materials or strategies comparing with other materials or strategies. So, after conducting experimental research, the researcher can draw conclusion whether his strategy is effective or not to be implemented in teaching and learning process based on the result shown.

In line with the researcher intention to conduct experimental study, the researcher examines the effect of independent variables on dependent variables. The independent variable of this study is teaching writing by using Wattpad as a medium and the dependent variables are students writing ability in writing. Pre-experimental research design is the design applied in this research. The students are given pre-test which functions as the starting point to see students' ability in writing. It is given before the treatment from the researcher. Meanwhile, the post-test is given after the treatment which functions as the determination to see whether there is any difference on students' ability between those in before and after the treatment. The aim is to see whether the treatment has better impact on students writing achievement by comparing the pre-test and post-test result.

This study is conducted in an EFL University setting in which the researcher could not randomly assign the subjects of the study. In many university situations in educational study, it is virtually impossible to randomly assign the subjects. Due to the limitation of randomly selecting the subjects, random assignment to treatment groups is not used. A pre-experimental design proposed by Cohen et al. (2007) is adopted by the researcher. The consideration of using adaptive design proposed by the researcher is the prohibition of changing the artificial groups for the purpose of the study. So, the most appropriate design is preexperimental design. Since this study uses pre-experimental as the design, the group given treatment is only one group. The results of the group are observed after some intervention or treatment presumed to cause changes. Although pre-experimental follows 
basic steps in experimental research, it fails to include group comparison. Randomization procedures cannot be done since the limitation of research involvement in sample chosen.

In this study, the class is employed using "Wattpad" as a medium on process-genre approach. Basically, the strategy comprises the same procedures compered in other experimental strategies. The group carries out the subsequent three stages of the experiment: (1) Administration pre-test, (2) Treatment, (3) Administration of Post-test. The pre-test is administered before the researcher giving the treatment. The researcher is given four meetings for the treatment and two meetings for pre-test and posttest. Prior to the treatment, the researcher prepares the research instruments that are going to be used in order to collect the data. Those instruments are writing tests for pre and post-tests and questionnaire for the students. The instruments are ready after validation process by experts. For the writing test, it is constructed by considering students major which is pharmacy. The suitable genre of their writing test is argumentative text. The participants are asked to create argumentative essay.

The assessors of students' works are the researcher and the English lecturer of the class. Before asking for help to the lecturer, some training is conducted to get the reliability of the scores on test. The researcher conducts the training by explaining the purpose and the function of the writing tasks. The next preparation is the researcher explains every aspect in analytic scoring rubric used in the study. The final score is the combination of the first and the second assessors. After preparing all the instruments needed and the assessors for conducting the study, the researcher and the teacher will begin the treatment for the group based on the schedule. The schedule is made by the teacher and the researcher based on the time allocation on delivering writing material. The teaching and learning process begun with pre-teaching activity and ended up with post-teaching activity. In the pre-teaching activity, the teacher did apperception starting from greeting the students, reviewing the previous materials, until describing what to be learnt. In the whilst-teaching stage, the teacher taught the materials to the students of the both groups. For the post-activity stage, the teacher asked for the students to do writing exercise.

The first meeting is used to administer the pre-test. Since the approach applied in this study is the collaboration between process-based approach and genre-based approach, the treatment begins by building students' knowledge in writing argumentative text. Modelling text is the next stage which collaborate with pre-writing activity. The teacher teaches the material to the students inserted by "Wattpad" activity. The third stage is joining construction of the text which is combined with drafting activity. Thus, the teaching and learning process is continued by applying independent construction of the text which requires the students with writing activity. Feedback given to the students writing product in revising stage. The last stage is editing students writing product and publish their writing product. Since the media is used for reinforcement, students writing products are uploaded in almost the end of the session. To sum up, the group had six sessions altogether and lasted 100 minutes for each meeting.

Table 1. Schedule for the Treatment

\begin{tabular}{cll}
\hline Meeting & Writing Process & \multicolumn{1}{c}{ Treatment } \\
\hline I & Writing & Pre-test \\
\hline II & BKoF & Teacher teaches how to write and analyse a good argumentative essay by giving \\
& $\begin{array}{l}\text { Pre-writing } \\
\text { MoT }\end{array}$ & $\begin{array}{l}\text { examples. (Teacher asks the students to read the article from Wattpad that is } \\
\text { shown in Appendix 4). }\end{array}$ \\
\hline III & MoT & $\begin{array}{l}\text { Teacher teaches students to read an argumentative and text from Wattpad and } \\
\text { analyze it (Appendix 5). }\end{array}$ \\
& $\begin{array}{l}\text { Pre-writing } \\
\text { JCoT } \\
\text { Drafting }\end{array}$ & $\begin{array}{l}\text { Teacher gives students task to write argumentative text and upload it in Wattpad. } \\
\text { Teacher gives feedback on students' work in Wattpad (Appendix 6). }\end{array}$ \\
\hline IV & ICoT Drafting, writing & Teacher gives students task to write argumentative text and upload it in Wattpad. \\
& Revising & Teacher gives feedback on students' work in Wattpad. \\
\hline V & ICoT & Drafting, Writing, Editing, and \\
& Revising & Post-test \\
\hline VI & Writing & \\
\hline
\end{tabular}

In the last day of giving the treatment to the students, the researcher distributes post-test to them. In the end of the experiment, the group is given post-test by the researcher. The aim of the post-test is to assess the students' writing mastery after being given treatment by the teacher. The result of the post-test would be analysed and compared with the result of the pre-test.

The data for analysing students writing achievement is obtained from this study. The quantitative data for students' achievement is obtained from the result of students' writing test before and after the treatment. The inter-rater reliability in scoring students writing product is applied. To get the reliable score from the raters, the researcher conducts some training. The tolerable scores gap from the raters is below 10. If the gap between the raters is more than 10 , the researcher will reassess the result of the student. The researcher decides to get the final score from the combination of the two raters. After the researcher getting the data from the students' writing test, those data will be analysed by checking and counting the scores based on rubric. 
Regarding to the research problems stated in previous part, the following procedures are employed to test the hypothesis and making the decision. The first step is set-up the null hypothesis. The null hypothesis is "There is no significant different in students' writing achievement taught by using Wattpad and those who are taught by using traditional one". The alternative hypothesis also be presented as follows "The students' writing achievement taught by using Wattpad is better than those who are taught by using traditional one".

The second step is setting the criterion for the decision. The criterion of acceptance or rejection of the null hypothesis is set. The researcher uses $95 \%$ level of confidence or $5 \%$ level of significance to know whether the differences is significant or not. By then, the criterion for the acceptance or rejection of the null hypothesis is a level of significance .05 or smaller.

The third step is calculating the result of the pre-test by using normality test. Determining whether the data normally distributed or not was the aim of calculating the data by using normality test. According to Larson-Hall (2010), formal test is one of the ways to check the normality of data through numerical examination. The most suitable formal tests that can be used to examine the normality in this study is Kolmogorov-Smirnov. Moreover, in line with Larson-Hall (2010) idea which conveyed that Kolmogorov-Smirnov is the most powerful test for sample size between 50-100. The distribution is normal if the probability is more than 0.05 .

The fourth step is analysing the data by using parametric statistical analysis. If the normality test has been fulfilled, the parametric test used in this study is pair t-test. The aim of analysing the data using pair t-test is to examine whether the means before and after the treatment is significantly different or not.

The final data is obtained by comparing the result of students pre-test and students post-test scores. The data will be analysed by using pair t-test. The use of pair t-test here is aimed to determine whether the difference of students writing achievement before and after the treatment is significant or not. Before applying pair t-test, there is an assumption of the study prior to the statistical calculation that need to be fulfilled. The assumption required is the variable being measured is from a normally distributed population. For fulfilling the assumption, the calculation is done by using SPSS. The average scores before and after the treatment are calculated and the standard deviation of the groups are squared by each deviation and total deviation. The result will be divided by the total number of the students. The analysis' aim is to know whether the technique proposed by the researcher significantly enhance students' writing achievement or not.

The last step is decision making of accepting or rejecting the null hypotheca. The average of control group is subtracted with the total of $\mathrm{z}$ multiply by the obtained Standard Error Measurement. If the result of statistical computation shows that the value fall in the critical value, it means that there is not enough statistical evidence to reject the null hypothesis or the alternative hypothesis is rejected. On the other hand, when the value does not fall in the critical region, it means that there is enough evidence to reject the null hypothesis.

\section{FINDING}

This section presents the data collected that is gained from the research. The data from students' achievement aspect is summed up. The description of the scores is aimed to illustrate students' writing achievement, especially in argumentative text. The data collected is assessed by two raters. This research administered two raters for assessing and scoring students' writing product. It is aimed to evade the subjectivity of grading the students' pieces of writing. The inter-rater approach of reliability estimates is calculated to confirm the reliability of pre-test \& post-test. The final scores of the students writing results is calculated by adding the score from the first and the second rater then divided by two.

The scores of students' writing test before (pre-test) and after (post-test) the implementation of using Wattpad by implementing the collaboration of process and genre-based approach were shown in Appendix 11 Measuring the two data was aimed to know the distinction of students' writing achievement before and after the treatment. The post-test for both of the control and experimental group was done on November $22^{\text {nd }}, 2018$. The post-test of the control group was at 10.20 AM to 12.00 PM. There were two out of 59 Students were absent. For the experimental group, the post-test was conducted at 10.20. AM to 12.00 PM. The total students who followed the post-test was 59 since none of the students absent.

Finding the effect of Wattpad was the aim of this study. To answer the research question of this research, the researcher analysed the data collected. The researcher used SPSS to calculate the means and standard deviation. The researcher compared the pre-test and the post-test scores. Moreover, the quality of students writing production is measured based on five aspects. Those five aspects consist of content, organization, grammar, vocabulary, and mechanic. Different weight given for each aspect.

The mean scores from five aspects after the treatment is higher than before the treatment. From the result, it showed that there was a difference in the achievements of the students before and after the treatment. The progress in the achievements of the students could be referred to the use of Wattpad as the medium. The mean of the pre-test was 71,97, and the mean of the post-test was 81,07. It is clear from this result that the treatment has an advantage comparing the pre-test with the post-test scores. The table above shows that the result of the treatment brought effectiveness for each aspect of writing ability. The aspect that increased are content (from 17,95 to 20,78), organization (from 15,97 to 17,25), grammar (17,22 to 19,58), vocabulary (from 15,42 to 16,88), and mechanic (from 5,41 to 6,58). In table 3 the standard deviation and standard error of students' score on the pre/post-test. 
The mean score of students writing product before the treatment is 71,97 while the mean score of students writing product after using "Wattpad" as a medium is 81,07 . The result of the mean pre-test scores are shown in table 2. To make it clearer, figure 1 and 2 show the chart of pre-test and post-test result.

Table 2. The Mean Scores of Students Writimg Result

\begin{tabular}{cccccc}
\hline & $\begin{array}{c}\text { Mean } \\
\text { (Average) }\end{array}$ & $\begin{array}{c}\text { N } \\
\text { Number of } \\
\text { Students }\end{array}$ & $\begin{array}{c}\text { SD } \\
\text { (Standart } \\
\text { Deviation) }\end{array}$ & $\begin{array}{c}\text { Min } \\
\text { (The Lowest Score) }\end{array}$ & $\begin{array}{c}\text { Max } \\
\text { (The Maximum Score) }\end{array}$ \\
\hline Pre-test & 71,97 & 59 & 6,52 & 59 & 89 \\
\hline Post-test & 81,07 & 59 & 5,26 & 62 & 91 \\
\hline
\end{tabular}

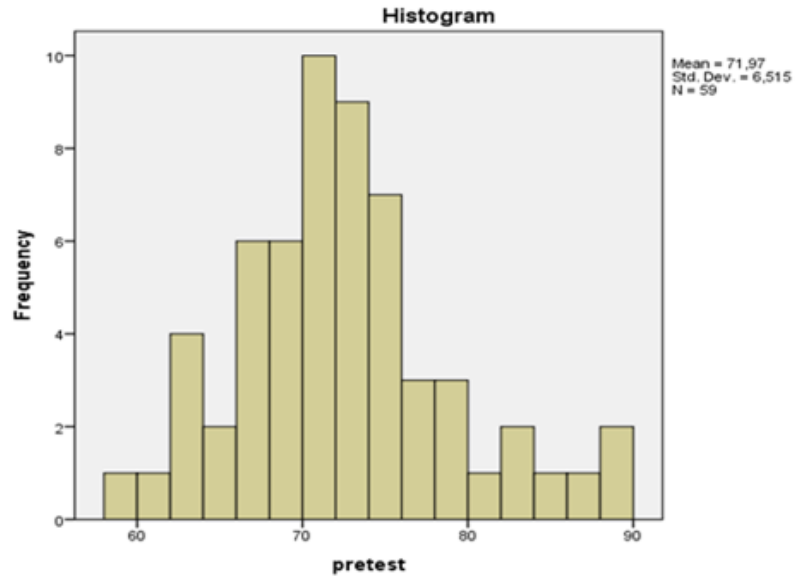

Figure 1. the histogram pre-test.

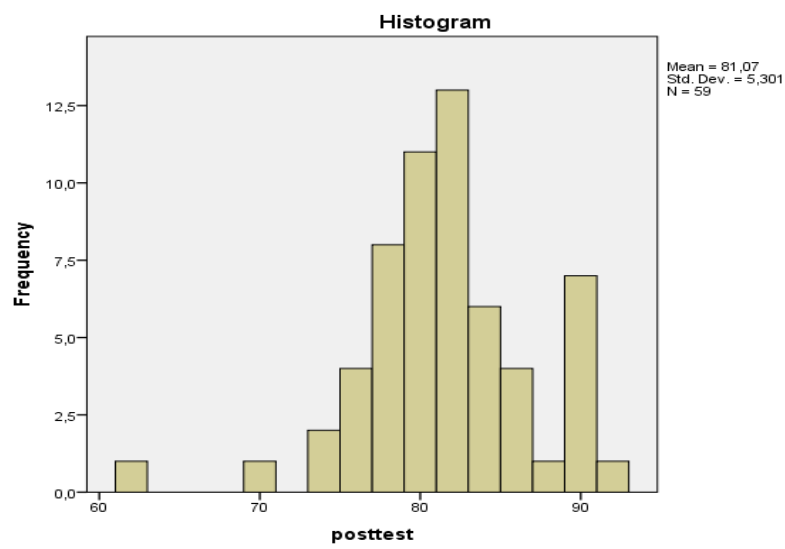

Figure 2. The Histogram post-test

Table 3. The Normality Test

\begin{tabular}{|c|c|c|c|}
\hline \multicolumn{4}{|c|}{ Test of Normality } \\
\hline \multicolumn{4}{|c|}{ Kolmogorov-Smirnova } \\
\hline & Statistic & Df & Sig. \\
\hline Pre-test & ,100 & 59 & 200 \\
\hline Post-test & ,108 & 59 & ,083 \\
\hline
\end{tabular}


The histogram in figure 1 and 2 show the graphic of students writing achievement before and after the treatment. Statistical calculation above showed the standard deviation obtained from pre-test was 6.515 and the standard deviation gained from post-test was 5.301. From the figure 1 and 2, the normality test could be conducted in table 3 . From the result of calculation based on Kolmogorov-Smirnov test, the significant level of pre-test was 0.200 and post-test was 0.083 . Since the minimum area which indicates that the pre-test and post-test normally distributed was 0.05 , both testes were normally distributed.

Since the normality test has been fulfilled, the next step was examining the data using parametric test. The parametric test used in this study is pair t-test. The reason behind using pair t-test was data gained from one class. So, it required the researcher to use pair t-test. The aim of analysing the data using pair t-test is to examine whether the means before and after the treatment is significantly different or not. The result of pair t-test can be seen in table 4 .

Table 4. Pair t-test for Students' Writing Achievment

\begin{tabular}{|c|c|c|c|c|c|c|c|c|c|}
\hline \multicolumn{10}{|c|}{ Paired Sample Test } \\
\hline & & \multicolumn{5}{|c|}{ Paired Differences } & \multirow[t]{3}{*}{$\mathbf{t}$} & \multirow[t]{3}{*}{ Sig. } & \multirow{3}{*}{$\begin{array}{c}(2- \\
\text { tailed })\end{array}$} \\
\hline & & Mean & $\begin{array}{c}\text { Std. } \\
\text { Deviation }\end{array}$ & $\begin{array}{c}\text { Std. } \\
\text { Error Mean }\end{array}$ & $\begin{array}{c}95 \% \\
\text { Interval }\end{array}$ & $\begin{array}{c}\text { Confidence of the } \\
\text { Difference }\end{array}$ & & & \\
\hline & & & & & Lower & Upper & & & \\
\hline $\begin{array}{c}\text { Pair } \\
1\end{array}$ & $\begin{array}{l}\text { Pre-test } \\
\text { Post-test }\end{array}$ & $-9,102$ & 6,053 &, 788 & $-10,679$ & $-7,524$ & $-11,549$ & 58 &, 000 \\
\hline
\end{tabular}

Table 4 showed that the $\mathrm{p}$ sig value was less than 0.05 (0.000). The $\mathrm{p}$ sig value gained indicated that students writing achievement after the treatment was significantly different. Statistical calculation above shows that there was enough evidence to accept the research hypothesis. The writing quality of ESP students taught by the use of "Wattpad" is higher than the quality of students' writing before taught by the use of "Wattpad". So, the result shows that the use of "Wattpad" make the quality of ESP students' writing product is significantly different.

\section{DISCUSSION}

The discussion of students' achievement in this study referred to the discussion of students' score on writing argumentative text which comprises of five aspects; content, organization, grammar, vocabulary, and mechanics. The result gained by the students was the calculation of the result rated by the raters. From the statistical view, it was found significant difference between students' pre-test and post-test. The mean of the pre-test was 71,97, and the mean of the post-test was 81,07 . The aspect of writing that increased were content (from 17,95 to 20,78), organization (from 15,97 to 17,25), grammar (17,22 to 19,58), vocabulary (from 15,42 to 16,88), and mechanic (from 5,41 to 6,58). It was clear from this result that the treatment influenced students writing achievement. It has an advantage comparing the pre-test with the post-test scores. The result indicated that students' writing product before and after the treatment were not similar. The calculation showed that the $\mathrm{p}$ sig value was less than 0.05 (0.000). The $\mathrm{p}$ sig value gained indicated that students writing achievement after the treatment was significantly different. Enough evidence to accept the research hypothesis had been fulfilled by the calculation.

The results gained after comparing students' achievement before and after the treatment (pre-test and post-test) showed how hard writing is. According to Cahyono and Widiati (2011), writing is believed to be the most complex skill among other language skills. Furthermore, (Davies, Tilman, \& Hiroyuki, 2017; Richards \& Renandya, 2002) stated that even in native language, writing is rarely done by most people. Lack of practice also makes writing as a difficult language skill. However, some solutions of writing difficulties have been found. One of the effective ways to overcome the problem was technology integration, especially by using Wattpad. The result of this study supported several learning theories (Kurt, Günüç, \& Ersoy, 2013) which showed the positive effect concerning technology, especially Wattpad.

The positive effect concerning the use of Wattpad have been stated by several studies (Aytan, 2017; Contreras et al., 2015; Ramdarshan Bold, 2018). The implementation of "Wattpad" proves that it could utilize the students with useful and meaningful learning in writing essay since they become more active and cooperative. Students have more bravery to express their opinions and ask questions. Feedback given by the teacher also became students' contemplation before they rewrite their writing product. Students also be able to learn from their mistakes. Wattpad also became part of the participants' lives. Students have been familiarized on using Wattpad since they had to figure the materials and publish their writing products on it. The researcher also helped the students by giving them examples of good argumentative text from Wattpad. This present study contributed to be additional support for the previous theories.

The positive effect of using Wattpad as English learning platform probably occurred due to two reasons. The first reason was Wattpad help students who had low English proficiency of failing to express their ideas on writing. Inadequate grasp of vocabulary and grammar become the basic problem of failing to express ideas in appropriate English (Hyland, 2003). However, 
this platform helped students on finding unfamiliar vocabulary and getting used to using correct grammar. Moreover, non-native writers generally write their writing product shorter, less cohesive, and contain errors. By using this platform, students were rehearsed to write longer, more cohhesive, and less mistakes/errors. This platform contributed to the furtherance of students writing expertise since they have enough vocabbulary and knowledge of grammar.

The second reason was Wattpad helped the students to achieve higher level of writing which requires cognitive domain of the writer and some basic skills. It was in line with some studies which revealed that writing is the most complex and difficult skill to master since it involves high cognitive skills (Hamman, 2005; Santangelo et al., 2008; Talebinezhad \& Negari, 2007; Villalon \& Calvo, 2011; Wahyuni, 2014). Wattpad helped the first cognitive skills which required learner to master in writing are related to collecting and relating information gathered which relevant to their topic. It also helped learner to organize information and ideas into logical sequence also required in writer's cognitive domain. The way of expressing information into written product and editing written draft into final drift also involved into cognitive skills that had been helped to be mastered. Hence, students gained both critical thinking and writing skills. Students were able to revise their won writing product critically.

Considering the role of Wattpad on writing, the finding of this study showed another factor influencing students' performances. One of the factors that influencing students' performance was modified approach. The process-genre based approach used in this study considers writing as practice than students writing result only. The combination between process and genre approach or commonly called as process-genre based approach once be done by Badger and White (2000). It brings fruitful result when it was implemented on teaching argumentative text writing for ESP students. The components contained in prosesgenre based approach are building knowledge, modelling, pre-writing, joining construction, drafting, constructing text individually, writing, revising, and editing. In Badger and White (2000) components, they removed joining construction and constructing text individually elements. The components in process-based approach was encountered in joining construction and constructing individual text. Modelling element and pre-writing in proses-genre approach were integrated to see the text produced by the students achieve the same criteria or not.

After applying the process-genre approach with clear instruction and in recursive way of process, the result support the study done by Badger and White (2000) and Yan (2005). Significant results of process-genre approach implementation on students' argumentative text achievement was gained after the implementation of the aforementioned approach and Wattpad as the medium. This present study did not support a study conducted by Mingli (2012) which gained failure since the result showed that the combination of process and genre approach was not more effective compared to the traditional one.

The students' success can be seen in some aspects. First, the way of developing the topic based on the theme. The materials about what to write, what the reason, what to refute, and what to sum up had been explained in building knowledge phase. On writing process, the students were given theme on their writing. The topics provided by the researcher were aimed to posit students' argument whether agree or not with the issues. Most of the students invited different point of view or perspective toward the issue. They succeed to develop cause-effect or compare-contrast paragraph like the examples given. Justified reason could be found in most of students' writing products. It made students reason could defend their point of view effectively. Those facts did not indicate students' lack of idea and references to be included in their reason.

Second, the content created by the students fulfilled the criteria of good content. The criteria of good content consist of developing the thesis thoroughly, expressing the logical reason clearly, and developing the reason thoroughly. According to (Susilo, 2015), Give supporting details, examples, cause-effect, and comparing-contrasting can be used as defensive arguments. Aforementioned ways of defensive arguments were the ways to refute opponents' reason. The subject of this study strived to defend their reason. They have the capability of refuting or proving that the opponents' reason was wrong. Only few of the students using abstract word to attack opponents' reason.

Third, students' organization fulfil the aspects of argumentative text, they are: introductory paragraph of an issue, reasoning paragraph, refuting paragraph, and conclusion. Students should provide thesis restatement, demand of action, and alternative solution. Involving all of the aforementioned aspects is used to strive defending students' argument and convincing the readers. Most of the students invited all of these aspects. Only few of them who gave reasons without posit at the topic in order to show their positions whether agree or disagree.

Fourth, the aspects of language were fulfilled to write good writing product. Correct grammar and giving suitable diction are the aspects of language. Feedbacks have been given by the researchers to students writing product. Researcher had given feedbacks to be learnt by the students. However, mistakes on grammar still be found in few students' writing products.

The fifth was the mechanical on writing. The aspects of a good writing product were the correct use of using punctuation, capitalization, and spelling. The correct used of transaction signals and spelling be found in the most of students' writing products. In fact, it happened the most before the treatment and reduced after the treatment. Nevertheless, there was significant difference between students' pre-test and post-test. Some aspects that were fulfilled by the students led students' post-test which had significant difference compared to students' pre-test. Obviously, the result of the treatment showed significant difference compared to students taught by using the traditional one. 


\section{CONCLUSION}

Based on the result showed in discussion section, it is found that students' achievement after the treatment is better than students' achievement before the treatment. Students' achievements before and after the treatment is significantly different which can be concluded that $\mathrm{H} 0$ is rejected and $\mathrm{H} 1$ is accepted. It means that there is significant difference between the class taught by using Wattpad with process-genre approach and the class taught by using the traditional one.

This study provides theoretical and practical contribution in English learning and teaching area. The information about how Wattpad affects students' achievement in writing is enriched by this study. Strategies of English language teaching, especially in writing is enriched by the existence of this study. It proves that theoretical contribution is brought by this study. In the term of practical contribution, this study is aimed to raise teacher awareness about the importance of technology implementation in English language learning. This study also be able to become reference about the implementation of technology, especially the use of Wattpad as writing medium for English learners. For future researchers, by observing the result of this study, they are expected to modify the treatment to give more precise result. Various method is expected to be applied by future researcher to figure out the multi effects of written feedback. Adding more variables also be expected to be done by future researcher.

\section{REFERENCES}

Abdul, M. (2014). The Effectiveness of Indirect Error Correction Feedback on The Quality of Students' Writing. Arab World English Journal (AWEJ), 5(2), 244-257.

Aytan, T. (2017). Evaluation of Electronic Writing Experiences of Turkish Teacher Candidates at WATTPAD Environment. Higher Education Studies, 7(4), 1-8.

Contreras, D. J. A. J., Gonzaga, H. G. N., Trovela, B. M. C., \& Kagaoan, M. A. C. G. (2015). The "wattyfever": Constructs of Wattpad Readers on Wattpad's Role in their Lives. Communication Research, 2(1), 308-327.

Davies, I., Tilman, G., \& Hiroyuki, K. (2017). Citizenship Education and Character Education. Journal of Social Science Education, 16(3).

Hamman, L. (2005). Self-Regulation in Academic Writing Task. International Journal if Teaching and Learning in Higher Education, 17(1), 15-26.

Hyland, K. (2003). Second Language Writing. Cambridge: Cambridge University Press.

Jenkins, H. (2006). Convergence Culture: Where Old and New Media Collide New York University Press. New York: New York University Press.

Kurt, A. A., Günüç, S., \& Ersoy, M. (2013). The Current State of Digitalization: Digital Native, Digital Immigrant and Digital Settler. Egitim Bilimleri Fakultesi Dergisi, 46(1), 1-22.

Ramdarshan Bold, M. (2018). The Return of the Social Author: Negotiating Authority and Influence on Wattpad. Convergence, 24(2), 117-136.

Richards, J. C., \& Renandya, W. A. (2002). Methodology in Language Teaching: An Anthology of Current Practice. Cambridge University Press.

Rifkin, J. (2014). The Zero Marginal Cost Society: The Internet of Things, the Collaborative Commons, and the Eclipse of capitalism. St. Martin's Press.

Santangelo, T., Harris, K. R., \& Graham, S. (2008). Using Self-Regulated Strategy Development to Support Students who have "Trubol Giting Thangs Into Werds." Remedial and Special Education, 29(2), 78-89.

Santoro, N., Reid, J.-A., Mayer, D., \& Singh, M. (2012). Producing "Quality" Teachers: The Role of Teacher Professional Standards. Asia-Pacific Journal of Teacher Education, 40(1), 1-3.

Susilo, H. (2015). Pengembangan Beberapa Kecakapan Hidup Abad 21 melalui Penelitian Tindakan Kelas Berbasis Lesson Study untuk Meningkatkan Kualitas Pembelajaran Matakuliah Fisiologi Tumbuhan. Prosiding Seminar Nasional Pendidikan Biologi 2015, yang Diselenggarakan oleh Prodi Pendidikan Biologi FKIP Universitas Muhammadiyah Malang,. Malang.

Talebinezhad, M. R., \& Negari, G. M. (2007). The Effect of Explicit Teaching of Concept Mapping in Expository Writing on EFL Students' Self-Regulation. Linguistics Journal, 2, 69-90.

Villalon, J., \& Calvo, R. A. (2011). Concept Maps as Cognitive Visualizations of Writing Assignments. Journal of Educational Technology \& Society, 14(3), 16-27.

Wahyuni, H. (2014). Increasing the Competence of VIII-B Class Students of SMPN 18 Malang in Writing Descriptive Text through Picture Cards as Visual Material Strategy. Skripsi tidak diterbitkan. Universitas Negeri Malang, Malang. 